\title{
The Use of Forest Areas for Infrastructure Development under Leasehold Forest Area License: A Sustainable Development Perspective
}

\author{
Suhadi $^{1 *}$ \\ ${ }^{1}$ Faculty of Law, Universitas Negeri Semarang, Semarang, Indonesia
}

\begin{abstract}
Infrastructure development (toll roads and geothermal exploration) in Central Java that uses forest areas does not conflict with the principles of sustainable development. Infrastructure development aims to provide technical or physical facilities that needed to provide services to the community and support the structure network so that the economic and social growth of the community can run well. Infrastructure development and forest area use aim to improve economic development and community welfare. The use of forest areas for infrastructure development carried out through borrowing permits for forest areas can still guarantee the sustainability of the functions and allotments of forest areas. The instrument that used to maintain the function and allotment of forest areas is to require holders of forest area use permits to conduct planting in the context of rehabilitation of watersheds, carry out reforestation on compensation land, carry out reclamation and / or reforestation in borrowed forest areas that are no longer used.
\end{abstract}

\section{Introduction}

The Ministry of Industry estimates that industrial land needs in Indonesia reach 1,200 ha. In the field of public works and public housing, based on the target of the Strategic Plan of the Ministry of Public Works and Public Housing, the need for land acquisition for 2015-2019 is estimated to reach 133,657 hectares, consisting of 21,172 hectares for the road sector, 111,437 hectares for water resources, 592 hectares for the field of copyright works, and 456 hectares for public housing. [1] The National Development Planning Agency of the Republic of Indonesia estimates that the need for land for infrastructure development reaches 140,704 hectares. The land area will be used for the construction of waste and waste water, drinking water, energy and electricity, railways, toll roads, airports, ports, dams and new public cities. [2]

Infrastructure development carried out in the Central Java region includes the construction of toll roads and geothermal exploration. The land needed for infrastructure development is partly located in forest areas. The construction of the Batang-Semarang toll road uses a permanent production forest area of Kendal Forest Management Unit (KPH) an area of 62,639 hectares [3]. Geothermal exploration activities use protected forest areas in Banyumas Regency and Brebes Regency, an area of 488.28 hectares. [4]

The method of obtaining land for infrastructure development located in the forest area is a Leasehold Forest Area License (LFAL). The use of forest areas for the construction of toll roads and geothermal exploration has caused some forest areas to no longer be overgrown with trees that are the main elements of the forest, thus reducing the function of forests, especially protection functions. The function of protecting forest areas is related to the function of forests to regulate water management, prevent flooding, control erosion, prevent sea water intrusion, and maintain soil fertility. In the mechanism of borrow-to-use forestry permit, the forest area contains the purpose of the forest area to be used non-permanently, but the fact is that the forest area used for the construction of the toll road is a permanent use. In the context of forest use, Zubayr stated that forest resources are shared resources which if used by someone will reduce their availability for others, but it is difficult to exclude those forest resource users. The use of forest resources without the support of strong institutions will result in open access to forest resources that will result in damage to forest resources, so to avoid this, the authority of forest management is in the hands of the government, or based on the law controlled by the state. [5]

\footnotetext{
* Corresponding email : suhadi@mail.unnes.ac.id
} 


\section{Objective of the study}

This paper will discuss the use of forest areas through LFAL for the construction of toll road infrastructure and geothermal exploration activities in the perspective of sustainable development. The main problem that will be answered through this paper is the regulation of forest area for infrastructure development through LFAL can guarantee the sustainability of the function of forest area

\section{Methodology}

The research method used in this research is normative law research [6] Sources of data in this study are secondary data in the form of primary legal materials, secondary legal materials, and tertiary legal materials, [7] consists of legislation relating to the use of forest areas and borrow-to-use forestry permit, as well as borrow-to-use forestry permit for forest areas for the construction of the Batang-Semarang toll road, and permits for geothermal exploration in Banyumas Regency and Brebes Regency, Central Java Province. Data analysis was done by using qualitative analysis.

\section{Discussion}

\subsection{Regulation of the Use of Forest Areas for Infrastructure Development}

Textually, there are no laws and regulations that specifically regulate the use of forest areas for infrastructure development. The existing legislation regulates the use of forest areas for development purposes outside the forestry sector. However, substantially it is within the scope of forest area use for development purposes outside the forestry sector.

According to Law No. 41 Year 1999 about Forestry, basically allows the use of forest areas for development purposes outside forestry activities. Forest areas that can be used for development outside forestry activities are production forest areas and protected forest areas, as stipulated in Article 38 of Law Number 41 year 1999. [8] The use of forest areas for development purposes outside the forestry sector in Government Regulation Number 24 Year 2010 in conjunction with Government Regulation Number 61 Year 2012 can only be made for activities that have inevitable strategic objectives. Activities that have strategic objectives are activities that are prioritized because they have a very important influence nationally on state sovereignty, national security, economic, social, cultural and / or environmental defense. [9] Strategic development activities are stated in a limited manner in Article 4 Paragraph (2) of Government Regulation Number 61 Year 2012 and the Regulation of the Minister of Environment and Forestry of the Republic of Indonesia Number P.50 /Menhut-II / Setjen/Kum.1/6/2016 namely (a) religion; (b) mining, (c) electricity generation, transmission and distribution installations, as well as new and renewable energy technologies, (d) construction of telecommunications networks, radio transmitting stations, and television relay stations, (e) public roads, toll roads, and railroad lines, (f) transportation facilities that are not categorized as public transportation facilities for the purpose of transporting production products, (g) facilities and infrastructure of water resources, construction of water installation networks, and clean water and / or wastewater channels, (h) public facilities, (i) industries other than forest product primary industries, (j) defence and security, (k) public safety supporting infrastructure, (l) temporary shelter for victims of natural disasters, (m) certain agriculture in the context of food security, (n) certain agriculture in the context of energy security, or (o) airport and port development. [10]

Development activities as mentioned in Article 4 paragraph (2) of Government Regulation Number 61 Year 2012 are categorized as infrastructure development, because they aim to provide technical or physical facilities needed to provide services to the community and support structural networks so that economic and social growth of the community can run well. Government Regulation Number 24 Year 2010 in conjunction with Government Regulation Number 61 Year 2012 in the case of borrow-to-use forestry permit or forest areas is further regulated in the Regulation of the Minister of Forestry of the Republic of Indonesia Number P.16 / Menhut-II / 2014 regarding the Guidelines for borrow-to-use forestry areas. In the Regulation of the Minister of Forestry of the Republic of Indonesia Number P.16 / Menhut-II / 2014 it is affirmed that the use of forest areas constitutes the use of part of the forest area for development purposes outside forestry activities without changing the function and designation of forest areas. The use of forest areas can be non-commercial or be commercial. 


\subsection{Leasehold Forest Area License for Toll Road Infrastructure Development and Geothermal Exploration}

The use of forest areas based on Government Regulation Number 10 Year 2010 in conjunction with Government Regulation Number 61 Year 2012 is carried out through borrow-to-use forestry permit (LFAL). It is the basis for the use of forest areas for development purposes outside forestry activities, including infrastructure development. It is given by the Minister who organizes government affairs in the forestry sector or governor for the construction of public facilities that are non-commercial. Through this permit, the use of forest areas is done without changing the function and designation of forest areas. Budiningsih, et al. explained that the policy on the use of forest areas through the mechanism of borrowing using forest areas contains that forest areas are used for development purposes outside the forestry sector, including for commercial purposes without changing their functions and designations. [11] This means that the function of the forest which includes the function of conservation, protection function and production function must remain.

The construction of the Batang-Semarang toll road partly uses a permanent production forest area in the area of the Forest Management Unit (KPH) Kendal, in Kendal District, Central Java Province. The forest area used is 62,639 hectares. LFAL is given by the Minister of Environment and Forestry of the Republic of Indonesia to the Minister of Public Works and Public Housing. [3] Geothermal exploration activities use protected forest areas in the Banyumas Regency and Brebes Regency, Central Java Province. The forest area used is 488.28 hectares. LFAL is given by the Minister of Environment and Forestry of the Republic of Indonesia to PT. Sejahtera Alam Energy. [4]

In Government Regulation Number 10 Year 2010 in conjunction with Government Regulation Number 61 Year 2012 and Regulation of the Minister of Forestry of the Republic of Indonesia Number P.16 / Menhut-II / 2014, efforts to maintain the function and allotment of forest areas due to forest area use through LFAL, are carried out with land compensation, compensation for paying non-tax state revenues (PNBP) the use of forest areas, and planting in the context of rehabilitation of watersheds. Land compensation is required for the use of forest areas located in provinces whose forest area is under 30\% (thirty percent) of the area of the watershed, island and / or province, with land compensation provisions with a ratio of at least 1: 1 for non-commercial and at least 1: 2 for commercial purposes. Compensation for paying Non-Tax State Revenues for the Use of Forest Areas and planting in the context of rehabilitation of watersheds, is required for the use of forest areas in provinces whose forest area is more than $30 \%$ (thirty percent) of the watershed, island and / or province, with provisions: 1. non-commercial use is subject to compensation for paying PKH PNBP and planting in the context of rehabilitation of watershed areas with a 1: 1 ratio; 2 . Commercial use is subject to compensation for paying PKH PNBP and planting in order to rehabilitate the watershed at least with a 1: 1 ratio. Only for national defense activities, means of sea or air traffic safety, check dams, artificial lake, dam, and facilities for meteorology, climatology and geophysics as well as survey and exploration activities, LFAL will be applied without compensation and planting in the context of rehabilitation of watersheds.

In the LFAL construction of the Batang-Semarang toll road, there is an obligation of its holders, including (1) providing and submitting compensation land for forest area use with a ratio of 1:2 within one year and can be extended for a maximum period of 2 years, (2) make plans and carry out reclamation and revegetation in forest areas that have not been used, pay the provision of forest resources and other financial obligations, (3) carry out forest protection in accordance with applicable regulations. [3] In LFAL geothermal exploration activities in the Banyumas Regency and Brebes Regency, there are obligations of LFAL holders, including (1) carrying out geothermal exploration activities which are good without damaging the environment, does not cause negative excesses to water resources, and does not affect sources hot springs around the forest, (2) carry out reclamation in unused forest areas, (3) pay for the provision of forest resources and reforestation funds, pay stumpage compensation to the government. [4]

\subsection{Principles of Sustainable Development in LFAL}

Sustainable development is often understood in terms of the Brundtland Commission's definition of "development that meets the needs of the present without compromising the ability of future generations to meet their own needs". At its core, sustainable development is about improving human welfare in ways that do not harm the environment, or more realistically it is about promoting economic development while using natural resources sustainably and minimising harm to ecological systems. [12] By referring to Harris, the use of forest areas for infrastructure development through LFAL is in line with the principles of sustainable development. Infrastructure development that uses forest areas aims to promote economic development in the framework of improving human welfare. Toll road construction is an infrastructure for the public interest which has a role in improving the welfare of the community. The decision of the Constitutional Court in adjudicating the case of Law No. 2 Year 2012 concerning Land Procurement, among others, states that "... the construction of toll roads is carried out for the 
smooth transportation of people, goods and services which are the necessities of life for many people. Even though it cannot be accessed freely by the poor, but with the existence of the toll road, both directly and indirectly the benefits will be felt to the entire community. In addition, with the existence of toll roads, heavy equipment of land transportation is largely diverted to toll roads so that the burden of public roads will be reduced, and thus will increase the security of public road users ". [13] Geothermal exploration is the first part of the development of geothermal power plants (PLTPB). In the Minister of Environment and Forestry Regulation P.50 / Menlhk / Setjen / Kum.1 / 6/2016 stated that the development interests outside forestry activities can be carried out for plant installation activities as well as new and renewable energy technologies including geothermal energy. In Law Number 30 Year 2009 about Electricity stated that electricity has a very important and strategic role in realizing the national development goals, so that the electricity supply efforts are controlled by the state and its provision needs to be continuously increased in line with the development growth so that sufficient electricity is available , distributed and has a good quality.

Minimizing harm to ecological systems is carried out by determining the obligations of LFAL holders after obtaining a permit, including: planting in the context of rehabilitation of watersheds, implementing reforestation on compensation land, carrying out reclamation and / or reforestation of borrow-to-use forestry permit that are not used. In other words, infrastructure development and forest area use are complementary in order to improve human welfare in ways that do not harm the environment or promote economic development while using natural resources to sustainably minimize ecological systems

\section{Conclusion}

Textually, there are no laws and regulations that specifically regulate the use of forest areas for infrastructure development. The existing legislation regulates the use of forest areas for development purposes outside the forestry sector. However, substantially the regulation of forest area use for infrastructure development is within the scope of forest area use for development purposes outside the forestry sector.

The development of toll road infrastructure and geothermal exploration aims to provide the technical or physical facilities that needed to provide services to the community and support the structure network so that the economic and social growth of the community can run well. The use of forest areas for infrastructure development through LFAL is in line with the principles of sustainable development. Infrastructure development that uses forest areas aims to promote economic development in the framework of improving human welfare. Minimizing harm to ecological systems is carried out by determining the obligations of its holders after obtaining permits, including: planting in the context of rehabilitation of watersheds, implementing reforestation on compensation land, carrying out reclamation and / or reforestation in forest areas that are not used anymore.

\section{References}

1. Suhadi. Prosiding Seminar Nasional Problematika Pertanahan dan Strategi Penyelesaiannya, (STPN and PSHA USAKTI, Jakarta, 2017)

2. Ministry of PPN / Indonesian Ministry of National Development Planning (Bappenas). Summary RPJMN 2015-2019. (KPPN/Bappenas, 2014)

3. Decree of the Head of the Investment Coordinating Board Number $2 / 1 / \mathrm{IPPKH} / \mathrm{K} / 2016$

4. Decree of the Head of the Investment Coordinating Board Number 20/1/IPPKH/PMA/2016

5. Zubayr, Manifas. "Policy Implementation of The Use of Forest Area for Mining Activity: Principal-Agent Relationship Perspective" Disertation. (Institut Pertanian Bogor, Bogor,2014)

6. Muhammad, Abdulkadir. Hukum dan Penelitian Hukum, (Citra Aditya Bakti, Bandung, 2004)

7. Soekanto, Soerjono and Sri Mamudji, Penelitian Hukum Normatif Suatu Tinjauan Singkat (RajaGrafindo Persada, Jakarta, 2012)

8. Law of the Republic of Indonesia No. 41 Year 1999 about Forestry

9. Government Regulation Number 24 Year 2010

10. Regulation of the Minister of Environment and Forestry of the Republic of Indonesia Number P.50/MenhutII / Setjen/Kum.1/6/2016

11. Budiningsih, Kushartati, Sulistya Ekawati, and Handoyo.JAKK Vol 13 (2016)

12. Harris, Paul G. Environmental Policy and Sustainable Development in China:Hong Kong in Global Context, (The Policy Press University of Bristol, UK, 2012)

13. Constitutional Court of Republic of Indonesia Decision Number 50/PUU-X/2012 